\title{
K-T magmatism and basin tectonism in western Rajasthan, India, results from extensional tectonics and not from Reunion plume activity
}

\author{
Kamal K. Sharma \\ Government Postgraduate College, Sirohi (Rajasthan) 307001 India \\ Email: sharmasirohi@yahoo.com
}

\begin{abstract}
Evolution of sedimentary basins took place in the Barmer, Jaisalmer and Bikaner regions during K-T (Cretaceous-Tertiary) time in western Rajasthan, India. These intra-cratonic rift basins developed under an extensional tectonic regime from early Jurassic to Tertiary time. Rift evolution resulted in alkaline magmatism at the rift margins. This magmatism is dated at 68.5 Ma and has been considered to be an early phase of Deccan volcanism. Deccan volcanism, sedimentary basin development and the alkaline magmatism of western Rajasthan have thus been considered to be the products of Reunion plume activity. However, sedimentary basin evolution began in western Rajasthan prior to Deccan volcanism and K-T alkaline magmatism. Gondwanaland fragmentation during the Mesozoic caused the development of the rift basins of Gujarat and western Rajasthan. This resulted in the opening of the Jurassic rift system and mildly alkaline magmatism at ca. $120 \mathrm{Ma}$ in western India. This event is pre-K-T and plume activity has not hypothesized for it. Continental fragmentation under an extensional tectonic regime during K-T time resulted in the magmatism and basin tectonism in western Rajasthan. Crustal development during the K-T period in western Rajasthan results from an extensional tectonic regime and is not the manifestation of Reunion plume activity.
\end{abstract}

Key words- K-T magmatism, mantle plume, western Rajasthan, extensional tectonics, K-T basins 


\section{Introduction}

The northwestern Indian shield has a unique evolutionary history extending from Precambrian to Tertiary time (Fig. 1, 2, 3). The crust in the region evolved through orogenic, anorogenic, magmatic, and granulite-exhumation phases during Precambrian time. The Aravalli, Delhi and Sirohi orogenies (Fig. 3), which date from approximately $1850 \mathrm{Ma}, 1400$ Ma and 830 Ma respectively, testify to the compressional tectonic regime that existed in the shield at those times. Rodinia fragmentation (at $\sim 750 \mathrm{Ma}$ ) resulted in a change from compressional to extensional lithospheric tectonism, and this in turn initiated development of the Malani Silicic Large Igneous Province (SLIP) in an intraplate rift setting in northwest India, Pakistan, and the Seychelles during the Neoproterozoic (750 -680 Ma; Sharma, 2004a, 2005).

The Phanerozoic geological evolution of this region has largely centered around formation of rift basins in response to global tectonic processes that resulted in separation of the Indian plate from Gondwana during Jurassic and Cretaceous times (Table 1, Figs. 2 and 3). The growth and geometry of Mesozoic to Tertiary basins have largely been controlled by NW-SE and NE-SW trending fracture systems (Fig. 2). The Phanerozoic crustal evolution of western Rajasthan was characterized by the development of three sedimentary basins, the Jaisalmer basin (Figs. 2 and 3), the Barmer-Sanchor basin (Fig. 2), and the Bikaner-Nagaur basin (Fig. 2), along with alkali magmatism at Mundwara, Sarnu and Tavidar (Fig. 3).

This chapter summarizes K-T magmatism and basin evolution in western Rajasthan. The Barmer-Sanchor rift (Fig. 2, 3) and associated alkaline magmatism resembles the Cambay and Narmada rift settings of the Deccan volcanic province (Fig. 1). The former has been interpreted as a pre-outburst phase of a plume currently under Reunion (Basu et al. 1993; Raval and Veeraswamy, 2000, 2003; Raval, 2001, 2003; Roy and Jakhar, 2002; Roy 2003, 2004). In this chapter I reappraise the tectonics commonly attributed to a postulated Reunion plume during the K-T period in western Rajasthan. I include a brief discussion of relevant lithologies, tectonic implications, and I present a viable working model for the tectonics of KT magmatism and basin evolution in western Rajasthan (Fig. 1)

\section{K-T magmatism in western Rajasthan}

\section{Mundwara Igneous Complex}

Coulson (1933) reported a suite of igneous rocks, popularly called the Mundwara igneous complex, west and northwest of the village of Mundwara in the Sirohi region (Fig. 3). This complex contains plutonic, hypabyssal and volcanic members ranging from ultrabasic to alkaline in composition. Srivastava (1988) on the basis of the intrusive nature of rocks at Sarnu and Tavidar (Fig. 3) into Cretaceous sandstones, proposed a Paleocene age for these rocks. Basu et al. (1993) reported a $68.5 \mathrm{Ma}$ age for the alkaline olivine gabbro. Rathore et al. (1996) using ${ }^{40} \mathrm{Ar} /{ }^{39} \mathrm{Ar}$ method analyzed several samples from the Mundwara region and reported a $70 \mathrm{Ma}$ age for the mafic rocks and $64 \mathrm{Ma}$ for the syenite. The reported ages for the Mundwara rocks are not coherent and more precise geochronology is needed. The isotope age of 68.5 Ma for the Mundwara rocks is interpreted as an early phase of the Reunion Hotspot activity in the region (Basu et al. 1993; Raval and Veeraswamy, 2000; Roy and Jakhar, 2002; Roy, 2003). 


\section{Tavidar Volcanic suite}

Agarwal (1984) described the petrography and geochemistry of the Tavidar volcanics (Fig. 3). Upadhyaya et al. (1988), on the basis chemical discrimination, divided the Tavidar volcanics into two groups: a) rhyolite, quartz-trachyte and trachyte, and b) basalts, including hawaiite and mugerite. The distribution behavior of major- and trace elements, and field relationships, indicate that the intermediate and acidic volcanics in the area are cogenetic, whereas the basalts are younger. Rathore (1995) reported a ${ }^{40} \mathrm{Ar} /{ }^{39} \mathrm{Ar}$ age of 64-66 Ma for the felsic rocks.

\section{The alkaline complex of Sarnu-Dandali}

The Sarnu-Dandali region is located at the eastern margin of the Cambay-Barmer basin in the Barmer region of Rajasthan (Fig. 3). The mildly alkaline igneous rocks (ca $120 \mathrm{Ma}$,) occur below Lower Cretaceous Sarnu sandstone in the Sarnu region (Chandrasekaran, 1987). Later, a variety of acidic, intermediate and alkaline magmatism took place during $\mathrm{K}-\mathrm{T}$ time. Basu et al. (1993) reported a mean age of the Sarnu-Dandali alkali pyroxenite of $68.57 \pm 0.08 \mathrm{Ma}$. The most common plutonic rocks are alkali pyroxenite, micrpmelteigite, melanephelinite, ijolite and feldspathic ijolite. The dikes are carbonatite, foidal syenites, phonolites and phonolite porphyries (Chandrasekaran, 1987).

\section{K-T Sedimentary basins}

The evolution of sedimentary basins in western Rajasthan began in the Mesozoic and continued into the Tertiary (Table 1, 2, 3, 4). The most important K-T basins are the Jaisalmer, Barmer, and Bikaner-Nagaur basins (Fig. 2).

\section{Jaisalmer Basin}

The Jaisalmer basin extends over $30,000 \mathrm{~km}^{2}$ in southwest Rajasthan (Fig. 2). It extends to the Mari region of Pakistan and forms part of the Indus Basin (Fig. 2). The basin is controlled by wrench-fault tectonics (Misra et al. 1993) and is divided into four tectonic elements; the Mari-Jaisalmer high shown by the Kanoi and Ramgarh faults (Fig. 2), the Shahgarh sub-basin (Fig. 2), the Miajalar sub-basin and the monoclinal Kishangarh sub-basin (Fig. 2).

The lowermost horizon in the Jaisalmer region is the Lathi Formation, which is of Jurassic age and named after Lathi village (Fig. 1) on the Pokaran-Jaisalmer road (Fig. 2, Tables 1 and 2 ). This horizon comprises a fluvial sequence of conglomerate and sandstone. The sandstone comprises several silicified land plant fossils (Das Gupta, 1975). After deposition of the Lathi Formation, a marine transgression occurred and the Jaisalmer basin formed. Marine sedimentation began with the Jaisalmer Formation, followed by the Baisakhi, Bhadasar, Pariwar and Habur Formations (Table 1 and 2). The Tertiary sequence in Jaisalmer basin is represented by the Sanu, Khuiala, Bandah and Shumar Formations. (Das Gupta, 1975).

\section{Bikaner-Nagaur basin}

The Bikaner-Nagaur basin (Fig. 2) is situated in the northern part of Rajasthan and comprises the Bikaner and Nagaur districts. Ghosh (1983) presented the Tertiary stratigraphy of the Bikaner basin (Table 3). Tertiary sedimentation began with the Palana Formation, which was 
deposited during the Paleocene in subtropical swampy conditions. The Marh Formation indicates encroachment of the sea during the Upper Paleocene to Lower Eocene. The Jogira Formation of Lower to Middle Eocene age succeeds this. There was complete withdrawal of the sea after the Eocene in this region, and the Kolayat Formation was laid down under fluvial, arid and eolian conditions from the Pleistocene to the Recent.

\section{Barmer Basin}

The Barmer basin lies in the southeast of the Jaisalmer basin, and it forms a north-south graben over $100 \mathrm{~km}$ length (Fig. 2). The Cambay rift basin extends northward through the Sanchor and Barmer basins (Fig. 1). The presence of Cretaceous-Paleocene volcanogenic sediments indicates that the Barmer basin developed as a composite, second-order graben. It contains predominantly terrestrial sediments ranging from Jurassic to Cretaceous in age. The Paleocene to Eocene period was marked by deposition of coastal, marine, shallow-water sediments.

The basal unit of the Barmer basin is the Fatehgarh Formation (Table 4). This Formation comprises mixed siliciclastic, carbonate and phosphorite rocks of Cretaceous age. Mathur et al. (2005) reported spherules, glassy balls, highly magnetic fine dust and micro-brecciated matrix and suggested that the spherules are related to the volcanic source or to K-T boundary impact ejecta from the Chicxulub impact in the Gulf of Mexico. However, more evidence is required to support this suggestion.

Sisodia et al. (2005) reported a 3-5 cm thick loose fragmental layer in siliceous earth from the Barmer basin, comprising volcanic debris such as glass shards, agglutinates, hollow spheroids, kinked biotites, feldspars, olivines, ilmenite and native iron. They suggested that the bands of siliceous earth were volcanic ash deposited during the Upper Cretaceous to Lower Paleocene. This suggests that development of the Barmer basin took place contemporaneously with Deccan volcanism.

\section{Reunion Plume Model}

Alkaline magmatism at Mundwara (Fig. 3) in north Cambay is interpreted as representing the earliest manifestation of the Reunion mantle plume in the northwest India (Basu et al. 1993). Mahoney et al. (2002) postulated a pre-Deccan marine phase of early Reunion hotspot activity after studying Cretaceous volcanic rocks in the south Tethyan suture zone of Pakistan.

Raval and Veeraswamy (2000) presented a detailed account of Reunion plume - continental lithosphere interaction in western India. The dynamics of this interaction were grouped into pre-, syn- and post-outburst phases; with the main plume outburst phase represented by the Deccan volcanism at $65.5 \pm 0.5 \mathrm{Ma}$ (Baksi, 1994; Basu et al. 1993). K-T magmatism and sedimentary basin development in western Rajasthan was considered to be pre-outburst plume activity, and included a) the Mundwara and Sarnu igneous complexes dated at $68.53 \pm$ $0.16 \mathrm{Ma}$ (Basu et al. 1993); b) a Pb-loss event dated at $\sim 70$ Ma from the Delhi-Aravalli region (Fig. 3) (Sivaraman and Raval, 1995); and c) the intraplate volcanism of Parh (Pakistan) at $\sim 70 \mathrm{Ma}$ (Mahoney et al. 2002). During this pre-outburst phase, the Indian plate was moving northward at the high velocity of $\sim 16-19 \mathrm{~cm} / \mathrm{yr}$ (Klootwijk et al. 1972), resulting 
in development of a linear corridor from the Parh group (Pakistan) through Sarnu-Dandali and Mundwara, to the Reunion plume outburst around Cambay (Fig. 1).

Roy and Jakhar (2002) and Roy $(2003,2004)$ endorsed the Reunion plume model (Raval and Veeraswamy, 2000, 2003) and suggested that Deccan volcanism, the Cambay-Barmer, Jaisalmer and Bikaner-Nagaur basins, and alkaline magmatism in Sarnu-Dandali, Tavidar and Mer-Mundwara, represent manifestations of plume-continental lithosphere interaction. The presence of high gravity anomalies, high heat flow and a seismic low-velocity zone below the Cambay-Barmer region were considered to be the geophysical expressions of Reunion plume impingement on the base of the Indian lithosphere. It was suggested that the bolide impact at the K-T boundary intensified already-ongoing plume volcanism in northwest India, though the mechanism of this is not clear (Roy, 2003; Roy and Jakhar, 2002).

\section{An alternative view}

The basement rocks outcropping in western Rajasthan are dominantly Neoproterozoic Malani rocks (750-770 Ma; Torsvik et al. 2001). Following the anorogenic Malani magmatism, the crust subsided and an intracratonic sag basin developed. This basin contains unfossiliferous, siliciclastic, carbonate and evaporite facies commonly known as the Marwar Supergroup (Fig. 3). The sedimentation in the Marwar basin continued up to Cambrian-Precambrian boundary.

Western Rajasthan remained almost tectonically dormant during the Paleozoic. With the exception of some glacial deposits laid down in the Permo-Carboniferous, no major sedimentary units were deposited in the region. K-T geodynamics in northwest India were complex and involved several major phenomena including development of the CambayBarmer rift, sedimentary basins in the Jaisalmer, Barmer and Bikaner regions, and alkali magmatism on the rift shoulders at Barmer, Tavidar and Mundwara. The mantle plume model has been invoked to explain various observations, but important factors such as continental fragmentation, the origin of the Arabian Sea, plate tectonics, the K-T mass biological extinction and the nature of postulated mass transfer from the core-mantle boundary to the surface, have not been adequately taken into consideration.

Sedimentary basin evolution began in western Rajasthan prior to Deccan volcanism and K-Tboundary alkaline magmatism. The Jurassic basin of Kutch (Fig. 1) and Jaisalmer in Rajasthan resulted from separation of the Indian continent from eastern Gondwana (Naqvi, 2005). The extensional regime resulted in opening of the Mozambique Ocean and development of the Jurassic rift system in western India. This is marked by mildly alkaline igneous rocks below the Lower Cretaceous Sarnu sandstone in the Barmer region (Fig. 3). Sedimentation ceased in the Barmer and Jaisalmer basins during the Upper Cretaceous $(\sim 85$ Ma). The marine regression from western Rajasthan during this period correlates with the break away of Madagascar from India (Torsvik et al. 2000). The separation of India and Madagascar resulted in tectonic changes that caused the sea to withdraw from western Rajasthan (Table 2).

The next phase of basin rejuvenation in western Rajasthan occurred during the K-T boundary period. This coincided with the separation of the Seychelles from India, large-scale Deccan volcanism, development of the Cambay rift and alkali magmatism in western Rajasthan. Crustal rifting during the K-T boundary period resulted in large-scale Deccan volcanism 
(Sheth, 2005a, 2005b) and development of the Cambay-Barmer rift system. The extensional tectonics resulted in deep fractures manifested by the development of rift basins, alkali magmatism and lamprophyre-carbonatite dykes. Mitra et al. (2006) described the Cambay basin as a classic example of an extension basin, which subsequently remained tectonically active and continued to exhibit graben subsidence, and horst- and fault bounded features. The development of the Cambay-Sanchor-Barmer rift caused reactivation of Precambrian fractures and resulted in magmatism at the basin margin at Mundwara, Tavidar and Sarnu (Sharma, 2004b).

\section{Non-Plume tectonism}

Tectonically the Jaisalmer basin comprises part of the shelf portion of the Indus geosyncline (Pareek, 1984). It is separated from the Bikaner-Nagaur (Fig. 2) basin by the PokaranNachana high (Fig. 2) to the northwest and from the Barmer basin by the Barmer-DevikotNachana high in the South (Fig. 2). A pronounced NW-SE trending regional step-faulted Jaisalmer-Mari high zone traverses the center of the basin. This high divides the basin into three parts. To the northeast is the monoclinal Kishangarh sub-basin (Fig. 2), to the south is Miajalar basin and to the southwest is Shahgarh sub-basin (Fig. 2). Zaigham and Mallick (2000) identified the Indus basin as an extension basin resulting from an inferred fossil rift crustal feature overlain by a thick sedimentary sequence. The extensional regime that resulted in the Indus basin initiated in the region as a result of divergence of the Indo-Pakistan subcontinent from Gondwanaland. The Indus basin (Fig. 1) is a fossil-rift feature and is characterized by horst and graben structures, together with a system of transcurrent faults. The origin of Jaisalmer basin is related to Indus basin evolution at the beginning of Triassic (Pareek, 1984) and not to "Reunion plume" activity.

The development of Bikaner-Nagaur basin in northwest Rajasthan is attributed to a plume by Roy and Jakhar (2002) and Roy (2003). The basin developed along east-west striking fault blocks in the Bikaner-Nagaur region, which extends westward into Pakistan. The Palana Formation (Table 3) constitutes the basal unit and was deposited under continental conditions and contains important deposits of lignite. Volcanogenic sediments and igneous activity are totally absent on the basin margins. Mafic and alkaline magmatism and other plume manifestations (Campbell, 2005) area also absent, arguing against plume-lithosphere interaction there. The Bikaner-Nagaur basin formed in relation to collision between the Indian plate and Tibet at around 55-50 Ma (Naqvi, 2005).

Raval $(2001,2003)$ attributed current seismicity in northwestern India to Reunion plume activity. In his model, plume-lithosphere interaction below western Rajasthan, the Cambay rift, and further south caused mantle upwelling, lithospheric thinning and a low-seismicvelocity zone, weakening the crust and resulting in the present seismic activity. Sharma (2006) argued against this unlikely scenario. He showed that the distribution of earthquake epicenters correlates with lineaments related to the palaeo-accretionary corridors, rift margins and fault zones. These pre-existing weak zones are vulnerable to reactivation and remobilize episodically. The northwestern Indian shield exhibits evidence for several geomorphological changes during the Quaternary. For example, western Rajasthan and Gujarat experienced rapid tectonic upheaval subsequent to the Vedic period (ca. 5000-10,000 years BC). The reason for the apparently constant reactivation throughout geological history of the region might be the weakened lithosphere, which is criss-crossed with faults, rather than plumeIndian lithosphere interaction. Courtillot et al. (2003) presume that the Indian plate drifted 
over a Reunion plume of deep-mantle origin, resulting in a large plume head upwelling below the Indian plate and K-T volcanism. However, mantle imaging shows the absence of evidence in the continental lithosphere supporting plume impact/incubation models beneath the Deccan volcanic province (Ravi Kumar and Mohan (2005).

The Barmer basin and associated alkali igneous complexes developed at basin margins during the K-T period. The Mundwara, Tavidar and Sarnu igneous complexes are interpreted as evidence for Reunion plume activity in western Rajasthan (Basu, et al. 1993; Raval and Veeraswamy, 2000; Roy 2003, 2004). Sharma (2004b, 2005), however, reports that these Tertiary alkaline complexes result from reactivation of the Precambrian Malani fracture system during the development of the Cambay-Barmer rift under an extensional tectonic regime (Fig. 3). This extensional tectonic regime developed during Mesozoic-Tertiary time as a result of Gondwana fragmentation (Sharma, 2004b).

\section{Summary}

Gondwanaland fragmentation during the Mesozoic resulted in extensional tectonics in the northwestern Indian shield. This led to the development of rift basins in Gujarat and western Rajasthan. Deccan volcanism, separation of the Seychelles micro-continent from India, sedimentary basin development in western Rajasthan and alkaline magmatism in Mundwara, Sarnu-Dandali and elsewhere have been postulated to be the products of Reunion plume activity in western India. However, basin development began in western Rajasthan during the Jurassic and such a plume cannot account for this. Continuation of the extensional tectonic regime resulted in deep fractures in the continental and oceanic lithosphere. The CambaySanchor-Barmer rift developed in the continental lithosphere. Mundwara, Sarnu-Dandali and Barmer magmatism, with nephelinite-carbonatite affinities at the basin margin, occurred in a typical rift-tectonic setting. Jaisalmer basin evolution is related to the Indus basin of Pakistan and does not have alkaline magmatism, volcanogenic sediments, or other plume manifestations. The Barmer basin is a typical rift setting with high rift shoulders and alkalinecarbonatite magmatism. The tectonic setting and crustal development of western Rajasthan during the K-T period thus occurred in a typical extensional tectonic regime and does not fit a model of Reunion plume activity.

\section{Acknowledgements}

I express a deep sense of gratitude to Prof. Gillian R. Foulger and Dr. Hetu Sheth for assisting and encouraging me in various ways in preparing this manuscript. I am thankful to Dr. Hetu Sheth for regularly providing me with important information. Manoj Pandit and an anonymous reviewer provided helpful reviews that improved the manuscript.

\section{References}

Agarwal, V., 1984, Geochemistry of the volcanic rocks around Tavidar, District Jalore, Rajasthan. Unpublished thesis, University of Rajasthan, Jaipur, 110 p.

Baksi, A. K. 1994, Geochronological studies on whole-rock basalts, Deccan Traps, India: Evolution of the timing of volcanism relative to the K-T boundary. Earth Planet, Science Letters v. 121, pp 43-56. 
Basu, A. R., Renne, P. R., Das Gupta, D. K., Teichmann, F., and Poreda, R. J., 1993, Early and late alkali igneous pulses and a high-3 He plume origin for the Deccan flood basalts: Science, v. 261, p. 902-906.

Bhandari A., 1999, Phanerozoic stratigraphy of western India: A review. In: P. Kataria (ed.) Geology of Rajasthan: Status and perspective. MLS University, Udaipur. p. 126-174.

Bhushan, S.K., 2000, Malani Rhyolite - A Review, Gondwana Research, v. 3(1), p. 65-77.

Campbell, I. H., and Griffiths, R. W., 1990, Implications of mantle plume structure for the evolution of flood basalts: Earth and Planetary Science Letters, v. 99, p. 79-93.

Campbell, I. H., 2005, Large Igneous provinces and the mantle Plume Hypothesis Elements: v.1, p. 265-269

Chandrasekaran, 1987, Geochemistry of the basic, acid and alkaline intrusive rocks of SarnuDandali area, Barmer District, Rajasthan, Unpublished thesis, University of Rajasthan, Jaipur, 108 p.

Coulson, A. L., 1933, The Geology of the Sirohi State, Rajasthan: Memoir Geological Survey of India, v. 63, 166 p.

Courtillot V., J. Besse, D. Vandamme, R. Montigny, J.J. Jaeger, H. Cappetta, Deccan flood basalts at the Cretaceous/Tertiary boundary? Earth Planet. Sci. Lett. 80 (1986) 361-374.

Das Gupta, S.K. 1974, Stratigraphy of the Rajasthan Shelf: Proc IV Indian Colloq. Micro. Stratigraphy, India. p. 219-233.

Das Gupta, S. K., 1975. Revision of the Mesozoic-Tertiary stratigraphy of the Jaisalmer Basin, Rajasthan: Ind. J. Earth Sci., v. 2, p.77-94.

Ghosh, R.N., 1983, Tertiary clay deposits of Kolayat and adjacent areas in Bikaner district: Rajasthan. Indian Minerals, v. 37(4), p. 56-69.

Klootwijk, C. T., Gee, J. S., Peirce, J.W., Smith, G.M., and Mcfadden, P.L. 1992, An early India- Asia contact: Palaeomagnetic constraints from Ninety east ridge, ODP leg 121. Geology, v.20 p. 395-398.

Mahoney, J. J., Duncan, R. A., Khan, W., Gnos, E., and McCormick, G. R., 2002, Cretaceous volcanic rocks of the South Tethyan suture zone, Pakistan: implications for the Réunion hotspot and Deccan Traps: Earth and Planetary Science Letters, v. 203, p. 295-310.

Mathur, S.C., Gour, S.D., Loyal, R.S., Tripathi, A., Tripathi, R.P. and A. Gupta, 2005, Occurrence of magnetic spherules in the Maastrichtian bone bed of the Fatehgarh Formation, Barmer Basin, India: Current Science, V. 89, p, 1259-1268

Misra, P.C., Singh, N.P., Sharma, D.C., Upadhyay, H., Kakroo, A.K. \& Saini, M.L., 1993. Lithostratigraphy of west Rajasthan basins: Oil and Natural Gas Commission, Dehradun, unpublished report.

Mitra, T, Maitra A. and Misra R.S.(2006) Syn-rift Tectonics and Depositional Pattern at North Cambay Basin, India Interplay of Basin Tectonics, Structural Style and Sedimentation: GEO 2006 Middle East Conference and Exhibition (March 27-29, 2006)

Naqvi, S.M., 2005, Geology and evolution of the Indian plate. (From Hadean to Holocene-4 Ga to $4 \mathrm{Ka}$ ) Capital Publishing Company, New Delhi, pp 1-448.

Pareek, H.S., 1984, Pre-Quaternary Geology and mineral resources of Northwestern Rajasthan: Memoir Geological Survey of India. v. 115. 1-95p.

Rathore, S.S., 1995, Geochronological studies of Malani volcanic and associated igneous rocks of southwest Rajasthan, India, implications to crustal evolution. Unpublished $\mathrm{Ph}$.D. thesis, M.S. University, Baroda. 175 p.

Rathore, S.S., Venkatesan T.R., Srivastva R.K. 1996 Mundwara alkali igneous complex, Rajasthan: Chronology and Sr Isotope systematic. Journal Geological Society of India. v. 48(5) p.517-528.

Raval, U. 2001 Earthquakes over Kutch: A region of 'trident' space-time geodynamics: Current Science, v. 8(97), p. 809-815. 
Raval, U. 2003, Interaction of mantle plume with Indian continental lithosphere since Cretaceous: Memoir Geological Society of India, v. 53 p. 449-479.

Raval, U., and Veeraswamy, K., 2000, The radial and linear modes of interaction between Mantle plume and continental lithosphere: A case study from western India. Journal Geological Society of India, v 56(5) p. 525-536.

Raval, U., and Veeraswamy, K., 2003, India-Madagascar separation: breakup along a preexisting mobile belt and chipping of the craton: Gondwana Research, v. 6, p. 467-485.

Ravi Kumar M. and Mohan G., 2005, Mantle discontinuities beneath the Deccan volcanic province Earth and Planetary Science Letters, v. 237, p, 252- 263.

Roy A. B. 2003, Geological and Geophysical Manifestations of the Reunion Plume-Indian Lithosphere Interactions-Evidence from Northwest India: Gondwana research, v.6(3), p. 487-500.

Roy A.B., 2004, The Phanerozoic Reconstitution of Indian Shield as the Aftermath of Breakup of the Gondwanaland, Gondwana research, v. 7(2), p. 387-406.

Roy, A.B. and Jakhar, S.R., 2002, Geology of Rajasthan (Northwest India) Precambrian to recent,. Scientific Publishers (India) Box 91, Jodhpur, p. 1-421.

Sharma K.K., 2004a, The Neoproterozoic Malani magmatism of the northwestern Indian shield: implications for crust -building processes Proc: Indian Academy Science (Earth Planet. Sci.), v 113(4) p. 795-807.

Sharma, K K., 2004b K-T magmatism of western Rajasthan, India: Manifestation of Reunion plume activity or extensional lithospheric tectonics? American Geophysical Union, Fall Meeting 2004, abstract \#V51B-0560 Pub code 2004AGUFM.V51B0560S.

Sharma, K. K., 2005, Malani magmatism: An extensional lithospheric tectonic orign, in Plates, Plumes \& Paradigms, edited by G.R. Foulger, J.H. Natland, D.C. Presnall and D.L. Anderson, Geological Society of America 388, p. 463-476.

Sharma, K.K., 2006, Intraplate Seismicity of the northwestern Indian shield: Implication for the reactivation of palaeo-tectonic elements. Geophysical Research Abstracts, V. 8, 03253, 2 European Geosciences Union 2006SRef-ID: 1607-7962/gra/EGU06-A-03253.

Sheth, H., 2005a From Deccan to Réunion: no trace of a mantle plume in Plates, Plumes \& Paradigms, edited by G.R. Foulger, J.H. Natland, D.C. Presnall and D.L. Anderson, Geological Society of America, 388, p. 477-502.

Sheth, H. C., 2005b, Were the Deccan flood basalts derived in part from ancient oceanic crust within the Indian continental lithosphere? Gondwana Research, v.8, p.109-127.

Sisodia, M. S., Singh, U. K., Lashkari, G., Shukla, P.N., Shukla, A. D., and N Bhandari 2005, Mineralogy and trace element chemistry of the Siliceous Earth of Barmer basin, Rajasthan: Evidence for a volcanic origin: Journal Earth System Science, v. 114 (2), p. 111-124.

Sivaraman, T.V. and Raval, U. 1995, U-Pb isotope study of zircons from a few granitoids of Delhi-Aravalli belt: Journal Geological Society of India v.46 p. 461-475.

Srivastava, R.K.,1988, Magmatism in the Aravalli mountain range and its environs, Memoir Geological Society of India, v. 7, p.77- 94.

Torsvik, T. H., Pandit, M. K, Redfield, T. F., Ashwal, L. D. and Webb, S. J. 2005, Remagnetization of Mesozoic lime stones from the Jaisalmer basin, NW India: Geophys. J. Int. 161, p 57-64.

Torsvik, T. H., Carter, L.M., Ashwal, L.D., Bhushan. S.K., Pandit M.K. and Jamtvit B.2001 Rodinia redefined or obscured: Palaeomagnetism of the Malani Igneous Suite (NW India) Precambrian Research, v. 108, p.319-333.

Torsvik, T. H., Tucker, R.D., Ashwal, L.D., Carter, L.M., Jamtveit, B., Vidyadharan, K.T. \& Venkataramana, P., 2000, Late Cretaceous India-Madagascar fit and timing of break-up related magmatism: Terra Nova, v. 12, p. 220-224. 
Upadhyaya, R., Srivastava, R. K., and Agarwal, V., 1988, A statistical approach to the study of an igneous suite- a case history of Tavidar volcanics. N. Jb. Mier. Abh., 159, v.3, p. 311-324.

Zaigham N. A. and K. Mallick, 2000, A Prospect of Hydrocarbon Associated with Fossil-Rift Structures of the Southern Indus Basin, Pakistan: AAPG Bulletin. v. 84; p. 11. 
Table 1 Phanerozoic stratigraphy of western Rajasthan, after Bhandari (1999).

\begin{tabular}{|c|c|c|c|c|c|}
\hline \multicolumn{3}{|c|}{$\overline{\text { AGE }}$} & $\begin{array}{l}\text { BARMER } \\
\text { BASIN }\end{array}$ & $\begin{array}{c}\text { JAISALMER } \\
\text { BASIN }\end{array}$ & $\begin{array}{c}\text { BIKANER-NAGAUR } \\
\text { BASIN }\end{array}$ \\
\hline \multirow{13}{*}{ 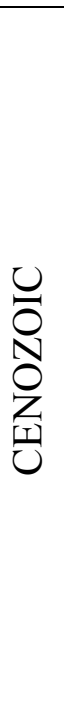 } & \multicolumn{2}{|c|}{ HOLOCENE } & \multirow{2}{*}{$\begin{array}{l}\text { Dune sands, alluvium } \\
\text { gravels } \\
\text { Utarlai Formation }\end{array}$} & \multirow[b]{2}{*}{ Shumar Formation } & \multirow{2}{*}{$\begin{array}{l}\text { Sand Dunes } \\
\text { Mar Formation }\end{array}$} \\
\hline & \multicolumn{2}{|c|}{ PLEISTOCENE } & & & \\
\hline & \multicolumn{2}{|c|}{ PLIOCENE } & & & \\
\hline & \multicolumn{2}{|c|}{ MIOCENE } & & & \\
\hline & \multicolumn{2}{|c|}{ OLIGOCENE } & & & \\
\hline & \multirow{5}{*}{ 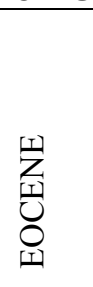 } & Priabonian & & \multirow{3}{*}{ Bandah Formation } & \multirow{5}{*}{ Jogira Formation } \\
\hline & & Bartonian & & & \\
\hline & & Lutenian & & & \\
\hline & & Ypresian & $\begin{array}{l}\text { Kapurdi Formation } \\
\text { Mataji ka Dungar Fm. }\end{array}$ & Khuiala Formation & \\
\hline & & & Akli Formation & & \\
\hline & \multirow{3}{*}{ 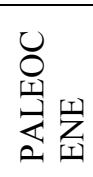 } & Thanetian & \multirow{2}{*}{$\begin{array}{l}\text { Barmer Formation } \\
\text { Fatehgarh Formation }\end{array}$} & \multirow{3}{*}{ Sanu Formation } & \multirow{2}{*}{ Marh Formation } \\
\hline & & Montain & & & \\
\hline & & Danian & & & Palana Formation \\
\hline \multirow{14}{*}{ 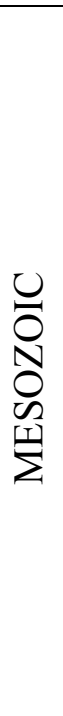 } & \multirow{7}{*}{ 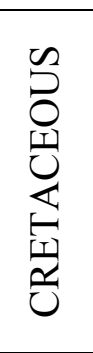 } & Santonian & & & \\
\hline & & Coniacian & & & \\
\hline & & Turonian & & & \\
\hline & & Cenomanian & & & \\
\hline & & Albian & & & \\
\hline & & Aptian & & Habur Formation & \\
\hline & & Neocomian & Sarnu Formation & Pariwar Formation & \\
\hline & \multirow{6}{*}{ 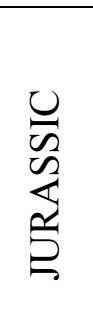 } & Tithonian & & Bhadasar Formation & \\
\hline & & Kimmeridgian & & Baisakhi Formation & \\
\hline & & Oxfordian & & & \\
\hline & & Callovian & Jaisalmer Formation & Jaicalmer Formation & \\
\hline & & Bathonian & & & \\
\hline & & Lias & Lathi Formation & Lathi Formation & \\
\hline & \multicolumn{2}{|c|}{$\frac{1}{\text { TRIASSIC }}$} & & & \\
\hline \multirow{5}{*}{ 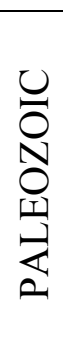 } & \multicolumn{2}{|c|}{ PERMIAN } & & & Badhaura Formation \\
\hline & \multicolumn{2}{|c|}{ CARBONIFEROUS } & & & Bap Boulder Bed \\
\hline & \multicolumn{2}{|c|}{$\begin{array}{l}\text { DEVONIAN to } \\
\text { ORDOVICIAN }\end{array}$} & & & \\
\hline & \multirow{2}{*}{\multicolumn{2}{|c|}{ CAMBRIAN }} & & & \\
\hline & & & Birmania Formation & Birmania Formation & $\begin{array}{l}\text { Nagaur Formation } \\
\text { Bilara Limestone }\end{array}$ \\
\hline \multirow{2}{*}{\multicolumn{3}{|c|}{ NEOPROTEROZOIC }} & Randha Formation & Randha Formation & Jodhpur Sandstone \\
\hline & & & $\begin{array}{c}\text { Malani } \\
\text { rocks/Basement } \\
\text { Complex } \\
\end{array}$ & $\begin{array}{c}\text { Malani } \\
\text { rocks/Basement } \\
\text { Complex } \\
\end{array}$ & Malani rocks \\
\hline
\end{tabular}


Table 2 Lithostratigraphy of the Jaisalmer basin (modified from Misra et al. 1993) and tectonomagmatic events relating to India and adjacent continents (Torsvik et al. 2005).

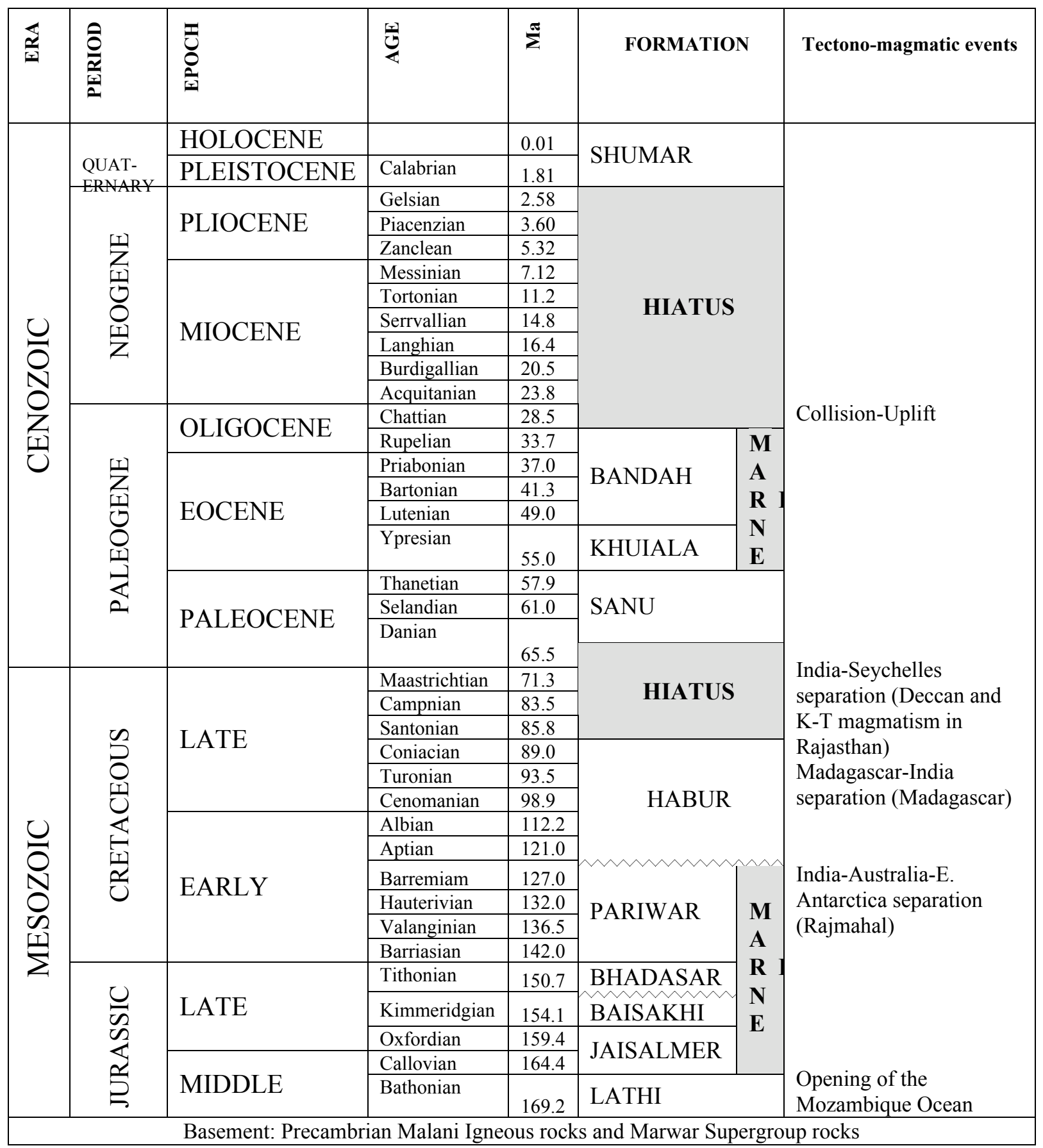


Table 3 Tertiary sequence of the Bikaner basin (Kolayat) region, after Ghosh (1983).

\begin{tabular}{|l|l|l|}
\hline $\begin{array}{l}\text { Pleistocene } \\
\text { to Recent }\end{array}$ & $\begin{array}{l}\text { Kolayat Formation } \\
\text { (Continental } \\
\text { fluvial, arid and } \\
\text { eolian facies) }\end{array}$ & $\begin{array}{l}\text { Conglomerates, ferruginous sandstone, ironstone } \\
\text { nodule, calcareous grot kankar, gypsite, sand and } \\
\text { sandy alluvium }\end{array}$ \\
\hline $\begin{array}{l}\text { Lower to } \\
\text { Middle } \\
\text { Eocene }\end{array}$ & $\begin{array}{l}\text { Jogira Formation } \\
\text { (Calcareous facies) }\end{array}$ & $\begin{array}{l}\text { Foraminiferal limestone, shale, marl and fuller's } \\
\text { earth }\end{array}$ \\
\hline $\begin{array}{l}\text { Upper } \\
\text { Paleocene }\end{array}$ & $\begin{array}{l}\text { Marh Formation } \\
\text { (Arenaceous facies) }\end{array}$ & Ferruginous sandstone, clay and shale \\
\hline $\begin{array}{l}\text { Lower } \\
\text { Paleocene }\end{array}$ & $\begin{array}{l}\text { Palana Formation } \\
\text { (Carbonaceous } \\
\text { facies) }\end{array}$ & Sandstone, carbonaceous shale and lignite \\
\hline
\end{tabular}


Table 4 Generalized stratigraphy of the Barmer Basin (after Das Gupta, 1974).

\begin{tabular}{|c|c|c|}
\hline Age & Formation & Lithology \\
\hline Recent & Dune sand and sediments & $\begin{array}{l}\text { Alluvium sands, river alluvium, and gravel } \\
\text { wash }\end{array}$ \\
\hline $\begin{array}{l}\text { Sub recent and (?) } \\
\text { older }\end{array}$ & Uttaralai Formation (3-4 m) & $\begin{array}{l}\text { Thin Gypseous limestone and salt } \\
\text { sequence, with unconsolidated sands, } \\
\text { kankar and gravel beds } \\
\text {-------Unconformity-------- }\end{array}$ \\
\hline \multirow{4}{*}{ Lower Eocene } & Kapuradi Formation $(30 \mathrm{~m})$ & $\begin{array}{l}\text { Lacustrine Fuller's earth deposits(?) } \\
\text { interbeded with marine bioclastic } \\
\text { limestone }\end{array}$ \\
\hline & $\begin{array}{l}\text { Mataji ka Dungar Formation } \\
(180 \mathrm{~m})\end{array}$ & $\begin{array}{l}\text { Shallow marine orthoquartzite and hard } \\
\text { sandstone with pisolite and ball clay and } \\
\text { impure bentonitic clay bands at the base } \\
\text {--------Unconformity--------- }\end{array}$ \\
\hline & $\begin{array}{l}\text { Akli Formation }(280 \mathrm{~m}) \\
\text { Akli Bentonite member } \\
\text { Thumbali Member }\end{array}$ & $\begin{array}{l}\text { Volcanogenic bentonite sequence at the top } \\
\text { and sandstone lignite sequence in the basal } \\
\text { part } \\
\text {--------Unconformity---------- }\end{array}$ \\
\hline & $\begin{array}{l}\text { Barmer Formation }(520 \mathrm{~m}) \\
\text { Madai member } \\
\text { Barmer hill Member }\end{array}$ & $\begin{array}{l}\text { Shallow marine sandstone with rare plant } \\
\text { fossils and orthoquartzite bands grading } \\
\text { into conglomerate, sandstone with plant } \\
\text { fossils and volcanogenic clays }\end{array}$ \\
\hline \multirow[t]{2}{*}{ Paleocene } & $\begin{array}{l}\text { Fatehgarh Formation }(520 \mathrm{~m}) \\
\text { Fatehgarh scarp Member } \\
\text { Vinjori Member }\end{array}$ & $\begin{array}{l}\text { Sunstone layer with mixed bivalve and } \\
\text { gastropod casts at the top. Dominantly of } \\
\text { ochreous clay bands, variegated sandy } \\
\text { siltstone and sandstone sequence with } \\
\text { coquina beds. } \\
\text {-------Unconformity--------- }\end{array}$ \\
\hline & Volcanic Formation (?) & $\begin{array}{l}\text { Acid to basic volcanic rocks mainly in } \\
\text { form of sills and dykes and local intrusive } \\
\text { porphyries }\end{array}$ \\
\hline Cretaceous & Sarnu Formation $(80 \mathrm{~m})$ & $\begin{array}{l}\text { Indurated, terrestrial sandstone and } \\
\text { siltstone with plant fossils } \\
\text {---------Unconformity---------- }\end{array}$ \\
\hline Callovo- Oxfordian & Jaisalmer Formation $(15 \mathrm{~m})$ & Marine, fossilferous, arenaceous limestone \\
\hline Bathonian to Lias & Lathi Formation (?) & $\begin{array}{l}\text { Terrestrial arenaceous sequence with wood } \\
\text { plant fossils and fossilferous tree trunks. }\end{array}$ \\
\hline Precambrian & Malani magmatism & Rhyolites, basalts and granite \\
\hline
\end{tabular}






Fig. 1 Map of northwest-central India showing the extent of the Deccan igneous province (shaded area), the Narmada rift valley, and the Barmer-Cambay rift and alkaline complexes. Arrow marks the approximate path of the postulated Reunion plume in the Late Cretaceous (after Campbell and Griffiths, 1990) 


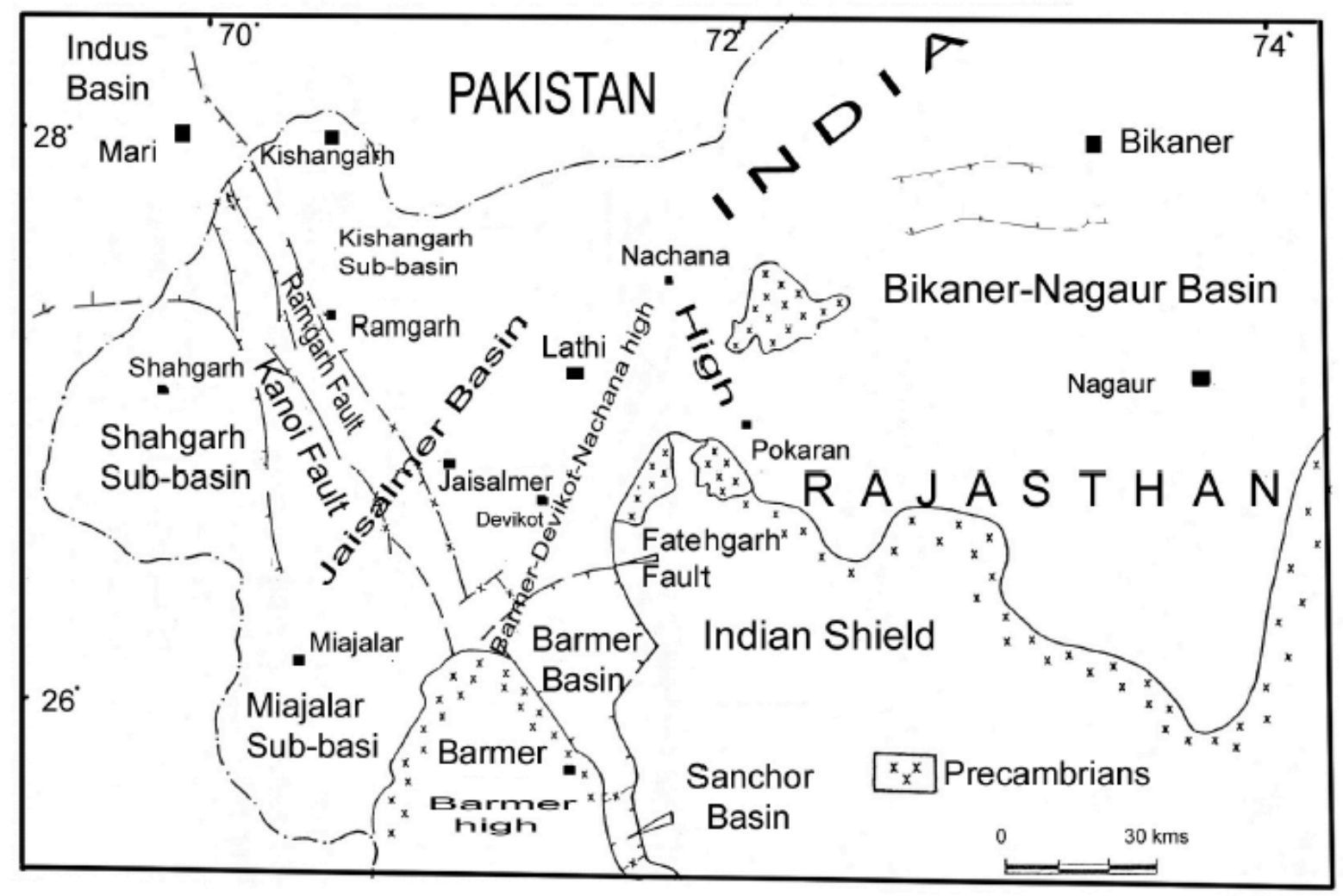

Fig. 2 Structural map of western Rajasthan (after Misra et al. 1993) 


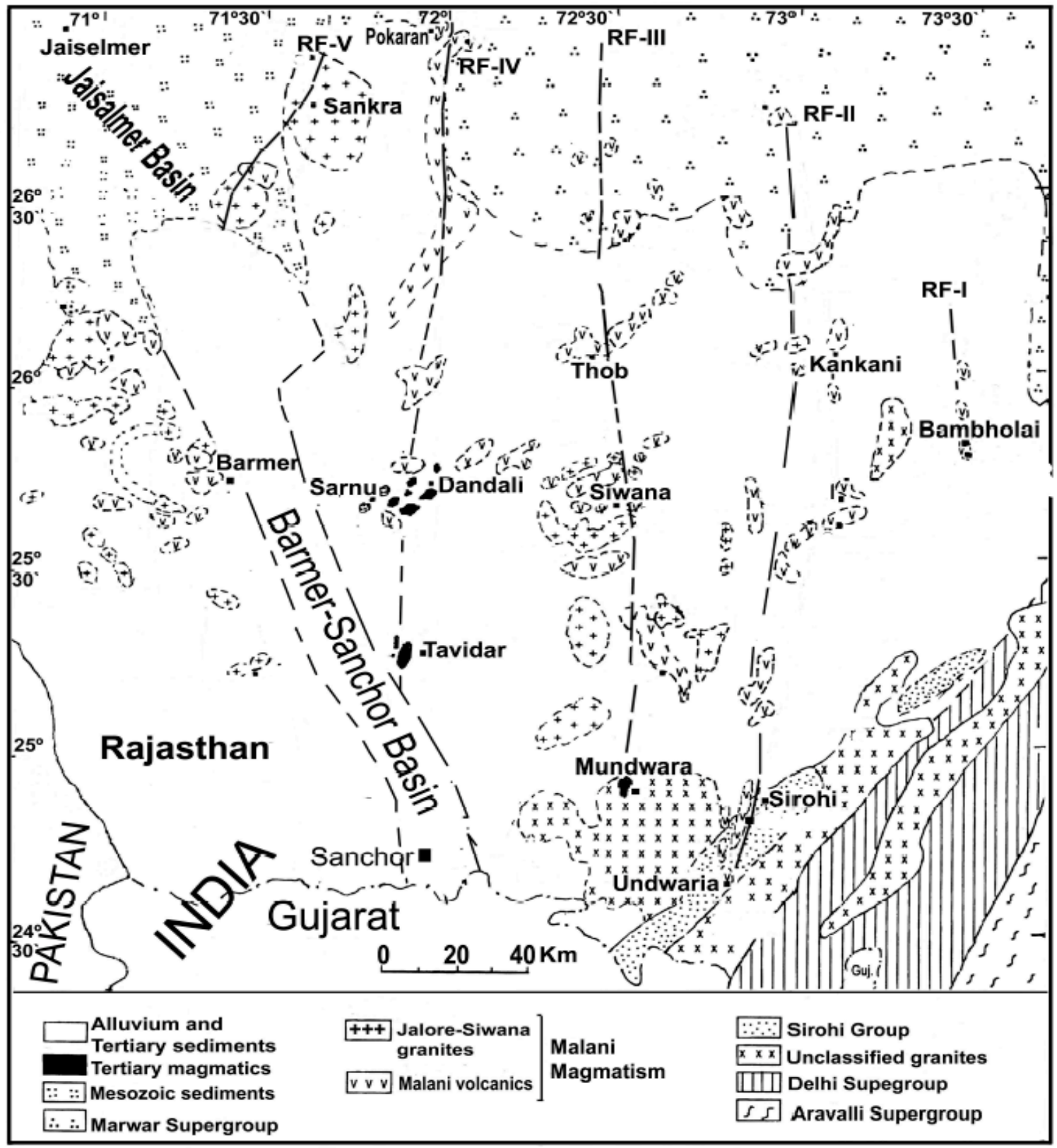

Fig. 3 Interpretive geological map of the Malani large igneous province indicating the roughly north-south-trending Neoproterozoic rift fractures (RF-I to RF-V), K-T BarmerSanchor basin and magmatism. Map modified from Bhushan (2000) and Sharma (2005). 